\title{
A New Form of Employment for Newly Arrived Migrant and Long-term Unemployed
}

Jenny Julén Votinius

\section{(2) OpenEdition}

1 Journals

\section{Electronic version}

URL: https://journals.openedition.org/rdctss/1846

DOI: $10.4000 /$ rdctss. 1846

ISSN: 2262-9815

\section{Publisher}

Centre de droit comparé du travail et de la sécurité sociale

\section{Printed version}

Date of publication: 1 December 2018

Number of pages: 264-267

ISSN: $2117-4350$

\section{Electronic reference}

Jenny Julén Votinius, "A New Form of Employment for Newly Arrived Migrant and Long-term

Unemployed", Revue de droit comparé du travail et de la sécurité sociale [Online], 4 | 2018, Online since 01 November 2021, connection on 15 November 2021. URL: http://journals.openedition.org/rdctss/1846 ; DOI: https://doi.org/10.4000/rdctss.1846

\section{cc)}

Revue de droit comparé du travail et de la sécurité sociale est mise à disposition selon les termes de la Licence Creative Commons Attribution - Pas d'Utilisation Commerciale - Pas de Modification 4.0 International. 


\section{JENNY JULÉN VOTINIUS}

FACULTY OF LAW, LUND UNIVERSITY

\section{A New Form of Employment for Newly Arrived Migrant AND LONG-TERM UNEMPLOYED}

November 2017, the Confederation of Swedish Enterprise and the Swedish Trade Union Confederation (LO) along with Unionen, Sweden's largest white-collar trade union on the private labour market, reached an agreement in principle on the introduction of a new form of employment to promote labour market participation for newly arrived migrants and long-term unemployed, called establishing-employment (etableringsanställning). A precondition for the agreement to be binding was that the State would agree to contribute to the wages.

In March 2018, following three months of negotiations, the Swedish Government and the social partners signed a declaration of intent whereby the Government agrees to support this joint initiative. ${ }^{1}$ Next, the Government will draft a state aid notification to be filed to the European Commission. There is also a need for legislative amendments in some areas. The necessary arrangements are expected to be in place in early 2019.

The establishing-employment will be open for newly arrived persons who have been granted residence permit in Sweden in the past 36 months, and for persons with more than twelve months of unemployment, or six months of unemployment for those below 25 years of age. The employed person must be allowed to participate in the national Swedish language course for immigrants (SFI) and other short courses during working hours, without any wage reduction. The Government has agreed to increase the number of training places, i.a. in vocational adult education. An establishing-employment can last up to two years. The aim is that the establishing-employment shall turn into a permanent employment after two years, but there is no guarantee that this will happen.

The wage in an establishing-employment must correspond to the minimum wage of the collective agreement, and it will give entitlement to social security benefits The Government has agreed to pay 54 percent of the wage costs, meaning that an employer's total payroll expenses for a position of this kind will amount to SEK 8400 (833 euro) per month. In addition, the employee will receive a tax-free, individual state benefit amounting to at most SEK 9870 (979 euro) per month in 2019. The Government and the social partners have agreed that the salary and the individual benefit shall follow wage developments.

1 Declaration of Intent of 5 March 2018 between the Government, the Swedish Trade Union Confederation (LO), Unionen and the Confederation of Swedish Enterprise.

http://www.government.se/49381d/contentassets/ae057fea761949e6950ad9a56dc81350/ declaration-of-intent-between-the-government-the-swedish-trade-union-confederatio-lounionen-and-the-confederation-of-swedish-enterprise.pdf 
The establishing-employment is an initiative of the social partners, and an employer who wants to make use of this form of employment must have a collective agreement. In order to prevent misuse, the social partners will establish a commission for the application of, and compliance with, union agreements on the matter.

On the sectoral level, collective agreements on establishing-employments will now be negotiated. The agreements will run over a five-year period. The white-collar trade union Unionen and a major share of the blue-collar trade unions within the Swedish Trade Union Confederation (LO) have agreed to participate in the initiative, but not all. For instance, the Swedish Building Workers' Union has opted out.

It is still uncertainty as to whether the necessary legislative changes will be approved by the Parliament. When the social partners presented their agreement in principle last year, several opposition parties took a strongly critical position, arguing that the State funding of the establishing-employments would present a too heavy burden on the taxpayers.

\section{NEW RULING ON THE USE OF PLASTIC UNDERARM COVERS FOR RELIGIOUS REASONS}

Sweden is a highly secular country, sometimes referred to as the least religious country in the Western world. ${ }^{2}$ Until recently, the issue of religion in business has not attracted much attention, and still, only a few cases have been tried before a court.

Discrimination on the ground of religion is prohibited in the Discrimination Act, which in 2009 replaced the then four separate acts on discrimination; on the grounds of gender, sexual orientation, disability, and ethnicity (including religion). The Discrimination Ombudsman has legal standing in discrimination cases, provided that the trade union refer from bringing action. When possible, the Ombudsman should always try to reach a reconciliation where the employer pays a damage without a court trial. Most discrimination cases are resolved through reconciliation, and only a very small number reaches the Courts. The vast majority of the reconciliations regarding discrimination on the ground of religion mediated by the Discrimination Ombudsman, as well as the majority of the few Court cases

2 P. Norris and R. Ingelhart, Sacred and Secular: Religion and Politics Worldwide, Cambridge University Press, New York, 2011, p. 257. See also "Sweden "least religious" nation in Western world», The Local 2015-04-13, referring to a study performed by WIN/Gallup International as part of its 2014 End of Year Survey. 
on the same matter, has concerned Muslims. ${ }^{3}$ The main topic has been the use of Islamic headscarfs, followed by the refusal to shake hand with people of the opposite sex. Most recently, the use of plastic underarm covers has been the focus on attention.

In 2016, the Stockholm District Court ruled in a case concerning a Muslim student in the dental program who was to begin her clinical training at Karolinska Institutet. ${ }^{4}$ According to the work place policy, which had been developed in accordance with guidelines from the National Health and Welfare Board, all clinical staff was required to work with bare underarms. Her application to wear plastic underarm covers due to religious convictions was declined. As the claimant was a student and the respondent was therefore the education provider, this case was not tried before the Swedish Labour Court. The District Court found that the requirement of bare underarms was more burdensome for some Muslim women compared to other groups. As it could not be established with certainty that plastic underarm covers caused genuine hygienic concerns, the District Court did not find that the education provider had succeeded in showing an objective justification of a possible indirect discrimination. The discrimination claim was thus approved. In line with this case, in August 2017, the Discrimination Ombudsman decided in a working life case regarding another large hospital. ${ }^{5}$ The authority made clear that the hospital could no longer upheld its requirement of bare underarms for staff at the maternity ward.

However, in December 2017, a very similar case was brought before the Labour Court, which came to quite the opposite conclusion. ${ }^{6}$ Notwithstanding the judgement in the case of Karolinska Institutet, the public dental care provider Folktandvården Stockholm upheld its requirement for all dentists to work with bare underarms. The Discrimination Ombudsman brought Folktandvården before the Swedish Labour Court, representing a Muslim dentist who was denied to wear plastic underarm covers. Just like in the Karolinska Institutet case, the Swedish Labour Court found that the requirement to work with bare underarms is more burdensome for some Muslim women compared to other groups, and that the case was to be tried as a case of indirect discrimination. Although the proof regarding the hygienic concerns was exactly the same as in the Karolinska Institutet case, the Labour Court found that the employer had succeeded in meeting the requirement for objective justifications.

3 In addition, recently, there has been a high profile-case concerning a Christian midwife who refused to perform abortions. That case is currently pending before the European Court of Human Rights.

4 Stockholm Municipal Court, case T 3905-15, Discrimination Ombudsman v The Swedish state through Karolinska Institutet (judgement 2016-11-16). Cf. P. Norberg, Country report Nondiscrimination - Sweden 2017, European network of legal experts in gender equality and nondiscrimination,

http://www.equalitylaw.eu/downloads/4388-sweden-country-report-non-discrimination-2017pdf-1-59-mb

5 Discrimination Ombudsman, decision GRA 2017/26 of 29 August 2017. http://www.do.se/globalassets/stallningstaganden/arbetsliv/tillsynsbeslut-sjukhus-kladregler-2017-1.pdf

6 Swedish Labour Court AD 2017 No 65, Equality Ombudsman, The Peoples Dentists of Stockholm County (Judgement 2017-12-20). 


\section{SWEDEN}

Even though it could not be established with certainty that plastic underarm covers caused genuine hygienic concerns, the Swedish Labour Court stated that a wide margin must be allowed for setting hygienic rules aiming at reducing risks regarding patient security. Hence, the discrimination claim was dismissed. 